\title{
Perspektif Kekuatan dalam Pekerjaan Sosial
}

\author{
Ishartono dan Santoso Tri Raharjo
}

\begin{abstract}
Abstrak
A lot of social issues generally approached the issue of problem-based approach (PBA) with a variety of other derivative terms, namely medical model, the deficit approach, or a more traditional approach. Problem-based approach to focus more on weaknesses in the client's self that causes problems, both at the micro, mezzo and macro levels. PBA is less attention to the potentials, aspirations, hopes and potential sources residing on the client and the client environment. Strength-based approach (strength perspective) as a perspective emerged in response to the previous approach. This approach started to pay attention to the potential, aspirations, expectations and resources that can be utilized within the framework of solving social problems. For the social work profession, this perspective provides a new angle to look at and address the social problems facing clients.
\end{abstract}

Keywords: Problem Based Approach, Strength Perspective, Social Work

\section{Pendahuluan}

Secara tradisional pekerjaan sosial telah lama menggunakan Problem Based Perspective atau Deficit Approach dalam penanganan masalah. Artinya intervensi Pekerjaan Sosial dalam mengatasi masalah, termasuk mengatasi kemiskinan, terfokus pada upaya mengatasi masalah atau kekurangannya. Bahwa secara tradisional para Pekerja Sosial menggunakan perspektif berbasis masalah ini dapat dipahami, mengingat "kelahiran Pekerjaan Sosial Profesional sangat dipengaruhi oleh ilmu kedokteran yang menggunakan "diagnostic approach" atau "pathologist approach". Seperti halnya diagnostic approach, Problem Based Perspective atau Deficit Perspective ini memandang penyandang masalah dari perspektif masalah atau kekurangan yang ada pada penyandang masalah. Asesmen yang dilakukan sebagai langkah awal pemecahan masalah terfokus pada permasalahan atau kekurangan serta kebutuhan klien, oleh karenanya treatment yang dilakukan terfokus pada mengatasi masalah atau kekurangan-kekurangan yang ditemukan pada tahap Assesment. Perspektif ini terus berlangsung hingga saat ini. Pada umumnya para Pekerja Sosial masih menggunakan perspektif tersebut.

Pada dua dekade terakhir muncul perspektif baru, yaitu "Strengths Perspective". Perspektif ini memfokuskan pandangannya terhadap penyandang masalah pada sisi kekuatan yang ada pada penyandang masalah, bukan pada masalah atau kekurangan. Perspektif ini memandang bahwa "setiap orang mempunyai sumber daya dan kapasitas untuk mengembangkan kehidupan mereka yang belum dimanfaatkan" (Saleeby dalam Graeme Stuart, 2012: 1) Dalam melaksanakan intervensi terhadap klien, Pekerja Sosial memfokuskan pada kekuatan yang ada pada klien, daripada masalah, kekurangan, dan hal-hal yang bersifat pathologis (Chapin, 1995; Early \& GlenMaye, 2000; Saleebey, 1992d; Weick et al., 1989, dalam Graeme Stuart, 2012: 1). Treatment yang dilakukan adalah mendayagunakan kekuatan-kekuatan klien yang dihasilkan dari asesmen, bukan mengatasi masalah klien. Perspektif ini muncul sebagai kritik terhadap praktik Pekerjaan Sosial yang menggunakan Problem Perspective atau Deficit Perspective. Penganut perspektif berbasis kekuatan ini berpendapat bahwa "pemecahan dengan menggunakan Problem Perspective atau Deficit Perspective tidak menghasilkan perubahan yang sustainable (Mount Royal University, 2011: 1) dan menciptakan ketergantungan pada sumber daya dan pemecahan masalah dari luar dirinya (Laura Ellis and Elaine Weekse, 2011: 1). 
Sebagai contoh dalam konteks penanggulangan kemiskinan, perspektif berbasis kekuatan ini berpandangan, bahwa orang miskin itu mempunyai kekuatan, mempunyai kapasitas untuk mengembangkan kehidupannya. Salah satu prinsip dari perspektif ini adalah "Every individual, family, group and community has strengths, and the focus is on these strengths rather than pathology" (Natalie Scerra, 2011: 3). Sebagai konsekuensi dari pandangan ini, maka asesmen terhadap orang miskin difokuskan pada kekuatan-kekuatan yang pada pada diri orang miskin tersebut. Treatment yang dilakukan tentunya difokuskan pada pendayagunaan kekuatan-kekuatan yang ada pada orang miskin sebagai tindak lanjut dari hasil asesmen. Hal ini berbeda dengan treatment yang menggunakan Problem Perspective atau Deficit Perspective yang terfokus pada penanggulangan masalah atau mangatasi kekurangan yang ada pada orang miskin sebagai tindak lanjut dari hasil asesmen. Artinya perbedaan perspektif tentang kemiskinan ini akan berdampak adanya perbedaan fokus asesmen antara kedua. Perbedaan fokus asesmen akan berdampak pada perbedaan fokus treatment-nya atau pemecahan masalahnya.

\section{Sejarah Perspektif Berbasis Kekuatan}

Seperti halnya profesi lain, profesi Pekerjaan Sosial juga telah mengalami berbagai perkembangan. Salah satu perkembangan yang terjadi adalah pergeseran perspektif dalam memandang masalah yang dihadapi klien. Perubahan perspektif terhadap masalah, tentu berdampak pada perubahan berbagai aspek dalam pemecahan masalah, misalnya metode, teknik-teknik, bentuk-bentuk kegiatan yang digunakan, dan lain-lainnya. Perubahan atau pergesaran perspektif itu adalah pergeseran dari perspektif berbasis masalah (problem-based perspective) ke perpsektif berbasis kekuatan (strengthsbased perspective)

Perspektif berbasis masalah atau problem based perspective ini disebut juga "the deficit approach, the problem-based approach". Perspektif ini digunakan dalam praktik Pekerjaan Sosial sejak "kelahiran" profesi ini. Perspektif ini terus digunakan oleh para Pekerja Sosial dalam menangani masalah sampai dengan munculnya perspektif berbasis kekuatan. Perspektif b e r basis masalah adalah cara pandang Pekerja Sosial dalam menangani masalah yang terfokus pada masalah-masalah atau kekurangan dan kebutuhan kliennya. Dengan perspektif ini tindakan-tindakan pertolongan yang dilakukan Pekerja Sosial terfokus pada tindakan untuk mengatasi masalah dan memenuhi kebutuhan kliennya.

Perspektif berbasis masalah ini sering disebut juga "pathologist approach", karena pengaruh pendekatan yang digunakan dalam praktik kedokteran, yang memang menggunakan pendekatan patologis atau "diagnostic approach". Secara historis kelahiran Pekerjaan Sosial sebagai profesi tidak dapat dilepaskan dari pengaruh praktik kedokteran, karena "dibidani" oleh seorang dokter (Mary Richmond). Perspektif berbasis masalah ini kemudian secara tradisional mendominasi praktik pemberian pertolongan yang dilakukan para Pekerja Sosial.

Dalam perjalanan praktiknya, muncullah pemikiran-pemikiran baru yang mengkritisi perspektif berbasis masalah. Pemikir-pemikir baru ini menilai bahwa perpspektif berbasis masalah mempunyai berbagai kelemahan. Laura Ellis and Elaine Weekse mengemukakan bahwa perspektif berbasis masalah dipandang tidak efektif untuk menghasilkan perubahan perilaku yang sustainable, bahkan menumbuhkan ketergantungan klien terhadap sumber-sumber di luar dirinya (2011: 1). Menurut Laursen (2003) pendekatan deficit akan memberikan dampak turunnya motivasi dan 
aspirasi untuk unggul (dalam Maryann Roebuck, 2007: 5). Mereka juga mengkritik perspektif berbasis masalah karena, perspektif ini menyebabkan terjadinya:

- Labeling, and therefore limiting options

- Obscuring the recognition of a person's unique capabilities and strengths

- Focusing on the "can 'ts" as opposed of the "cans"

- Ignoring potential resulting from adversity

- Prescribed programming-as opposed to individualized

- Looking for patterns, such as broken homes, dysfunctional neighborhoods, and poverty, to explain difficulties

- Lacking credibility to clearly show cause versus effect

(Wayne Hammond, 2010:1)

Dengan perspektif patologis, diagnosis sering kali menghasilkan label dalam mendefinisikan masalah klien. Labeling ini sering kali memiliki makna negatif yang sangat kuat di dalam masyarakat, sehingga sering membahayakan orang. Yang paling rentan adalah orang miskin, minoritas, perempuan, imigran. (Morley D. Glicken, 2011: 48). Label ini memiliki kekuatan tidak hanya untuk menjelaskan, tapi ternyata juga membatasi dan menyempitkan peluang klien untuk merealisasikan kehidupan yang lebih berarti (Clay Graybeal, 2001: 237). Karena itulah, sudah saatnya memandang orang miskin dari sisi yang lain, yaitu sisi positif atau sisi kekuatan dari orang miskin. Memandang orang miskin dari sisi kekuatan akan menghilangkan atau sekurang-kurangnya menghindarkan labeling bagi orang miskin tersebut.

Kita seringkali keliru memberikan persepsi terhadap orang miskin. Kita sering kali berpikir bahwa orang-orang miskin itu senantiasa menunggu uluran tangan kita, menunggu bantuan kita, menunggu amal kita, padahal pikiran kita ini tidak selalu benar. "Secara keseluruhan orang miskin tidak mencari amal kita; mereka mencari kesempatan untuk menggunakan keterampilan dan tenaga mereka untuk memperbaiki keadaan mereka" (John, 2011). Mereka adalah orang-orang yang selalu mencoba berusaha untuk memperoleh sesuatu guna memenuhi kebutuhan hidup mereka. Hanya saja, kemampuan dan kesempatan yang tidak mampu mereka capai menyebabkan secara sasat mata seakan-akan mereka adalah oraang-orang yang tidak berdaya, yang hanya dapat menunggu bantuan atau tindakan amal orang lain. Oleh karena itu, sudah saatnya persepsi terhadap orang miskin ini diubah. Dalam ungkapan yang lebih prospektif Prahalad (2009) mengemukakan "Jika kita berhenti memandang orang miskin sebagai korban atau beban dan mulai mengenali mereka sebagai pengusaha yang tangguh dan kreatif, sebuah dunia baru berpeluang akan terbuka". Lebih lanjut Prahalad mengemukakan bahwa orang miskin bukanlah penguras sumber daya dari orang-orang kaya di dunia ini. Mereka itu dapat menjadi sumber inovasi dan pada akhirnya justru menjadi mesin perputaran perdagangan global dan kemakmuran.

Kritik-kritik ini kemudian menghasilkan munculnya perspektif berbasis kekuatan, meskipun perpsektifini tidak serta merta mendominasi perspektif dalam praktik Pekerjaan Sosial. Kapan perspektif berbasis kekuatan ini muncul dalam praktik intervensi Pekerjaan Sosial? Sebetulnya sulit mengetahui waktu kelahiran perspektif ini. Sebelum perspektif berbasis kekuatan ini dinyatakan, sudah ada beberapa pendekatan yang sangat mirip dengan perspektif berbasis kekuatan, seperti "development resilence", "healing and wellness", "solution focused therapy", "asset-based community development". (Dennis Saleebey, 2002). Istilah-istilah tersebut merupakan wujud dari pergeseran cara berpikir para pekerja 
sosial dalam memandang permasalahan yang dihadapi kliennya. Perspektif berbasis kekuatan atau "the strengths-based perspective" itu sendiri mulai digunakan sejak tahun 1980.

Bahwa perspektif berbasis kekuatan memandang penyandang masalah dari masalahnya tetapi dari kekuatannya, bukan berarti perspektif ini menyangkal adanya masalah. "It is important to understand the strengths-based approach is not about denying that people do experience problems and challenges and these issues do need to be taken into consideration of a more holistic approach". (Wayne Hammond, 2010:1). Dalam bahasa yang lain Saleebey mengemukakan bahwa "perspektif kekuatan bukan berarti meninggalkan sama sekali model medik atau patologis. Schizophrenia adalah nyata. Kekerasan seksual adalah nyata" (Dennis Saleebey, 2001:233). Demikian pula, kemiskinan itu nyata. Perpsektif berbasis kekuatan tidak menolak adanya kenyataan bahwa orang mengalami kemiskinan. Perspektif ini hanya melihat sisi atau dimensi lain dari penyandang masalah.

Berbeda dengan perspektif berbasis masalah, perspektif berbasis kekuatan lebih memfokuskan pada kekuatan dan sumber daya. Perspektif ini meyakini bahwa setiap orang, tanpa kecuali, mempunyai asset internal dan eksternal, kompetensi, serta sumber daya (Dennis Saleebey, 2000: 127). Kedua perspektif tersebut memperlihatkan perbedaan cara pandang terhadap orang yang bermasalah dibandingkan dengan orang yang "tidak bermasalah". Perspektif berbasis masalah memandang bahwa "seseorang itu bermasalah, sedangkan orang lain tidak bermasalah". Ada labelling yang dikenakan kepada orang bermasalah. Di sisi lain, perspektif berbasis kekuatan memandang bahwa "seorang yang bermasalah itu mempunyai kekuatan, sedangkan orang yang tidak bermasalah juga mempunyai kekuatan". Tak ada label atau setidak-tidaknya ada label yang sama yang dikenakan kepada orang yang bermasalah.

Pergeseran perspektif pemecahan masalah telah terjadi dalam praktik Pekerjaan Sosial dari perspektif berbasis masalah (deficit perspective atau problem perspective) ke perspektif berbasis kekuatan (strength perspective).

This paradigm can influence one's view of all behavior, and have a profound effect on how services are provided, especially through the dichotomization of all behavior into medical and non-medical polarities, and through the mechanism of insurance coverage and reimbursement (Berlin, 1992; Kirk \& Kutchins, 1992)

Paradigma tersebut dapat mempengaruhi cara pandang seseorang terhadap perilaku, dan berdampak pada bagaimana layanan disediakan, terutama melalui dikotomi semua perilaku terbagi menjadi medis dan non medis, dan melalui mekanisme layanan asuransi dan kompensasi (Berlin, 1992; Kirk \& Kutchins, 1992).

The fundamental premise is that individuals will do better in the long run when they are helped to identify, recognize, and use the strengths and resources available in themselves and their environment.This seems harmless enough, but as the author and his colleagues have witnessed, this simple idea can be seen as very threatening by some (Clay Graybeal, 2001: 234)

Perspektif kekuatan dapat dikatakan sebagai suatu metode khusus dalam bekerja bersama dengan klien serta berdasarkan pengalaman-pengalaman klien dalam mengatasi masalah-masalahnya. Hal ini bukan berarti mengabaikan kesulitan-kesulitan atau masalah-masalah yang dialami. Bah- 
kan lebih dari itu, yaitu berupaya mengidentifikasi hal-hal positif berdasarkan sumber-sumber yang berada di seputar klien serta keterampilan-keterampilannya sebagai pijakan untuk mengatasi berbagai persoalan.

\section{Prinsip-Prinsip Perspektif Berbasis Kekuatan}

Telah dikemukakan sebelumnya bahwa Pekerjaan Sosial lahir dengan didasari oleh perspektif berbasis masalah yang patologis. Dalam perjalanannya para praktisi maupun akademisi Pekerjaan Sosial telah banyak mengembangkan teori maupun praktik dengan berbasis pada masalah. Pekerjaan Sosial berkembang sebagai profesi "pemberian pertolongan".

Social work has constructed much of its theory and practice focusing on deficits, problems, pathologies, and diseases (Minuchin et al., 1998; Lawrence, 2004; Seligman \& Darling, 2007). Throughout its history, social work has been seen as a problem-solving profession. In other words, the foundation of social work during the past hundred years has been the traditional problem-solving model, sometimes called a "positivistic", "deficit" or "medical model" (Berg, 1994; de Jong \& Berg, 2002a; Healy, 2005). This model, rooted in cultural and belief systems, arose in the field of medicine in the late 19th and early 20th centuries and has been the dominant paradigm of practice in the helping profession. In the problem-solving paradigm, the specialist as the "expert" usually designs the solution (Berg \& Kelly, 2000: 15). ${ }^{1}$

Teori-teori dan metode-metode, pendekatan, dan lain-lain dengan basis masalah ini telah menjadi dasar praktik pekerjaan sosial selama ini. Hingga awal abad ke 20 basis masalah yang menjadi dasar perspektif dalam pengembangan teori maupun metode Pekerjaan Sosial ini sangat dipengaruhi oleh pendekatan yang digunakan dalam dunia kedokteran selama ini yang didominasi pendekatan patologis, sampai munculnya perspektif baru, yaitu perspektif berbasis kekuatan. Perspektif berbasis kekuatan memandang bahwa pendekatan yang terfokus pada masalah dapat menghilangkan kekuatan-kekuatan yang ada pada keluarga, sumber daya, serta motivasi untuk berubah.

Dalam implementasinya perspektif berbasis kekuatan ini menggunakan suatu prinsip. Prinsip yang mendasarinya adalah bahwa "individu-individu akan berperilaku baik di masa depan ketika mereka dibantu untuk mengidentifikasi, mengenali dan menggunakan kekuatan-kekuatan dan sumber daya-sumber daya yang tersedia dalam diri mereka sendiri dan dalam lingkungan mereka" (Graybeal, Moore, \& Cohen, 1995). Kekuatan dari perspektif kekuatan ini sebetulnya juga berasal dari nilai-nilai yang ada pada Pekerjaan Sosial itu sendiri, seperti "Self determination, empowerment, worth and human dignity”. (Cummins, Sevel, \& Pedrick, 2006).

The strengths perspective as a philosophical principle of social work practice emanates from social work values: self-determination (the act of giving clients the freedom to make choices in their lives and to move toward established goals in a manner that they see as most fitting for them), empowerment (lays the groundwork for informed self-determination), inherent worth and dignity (a core value of the profession is respect for every human being's) (Cummins, Sevel, \& Pedrick, 2006).

${ }^{1}$ https://sites.google.com/site/solutionfocusedapproach/5-study-materials/2-strengths--basedapproach-definition-history-philisophy-principles-and-practice. 
Berdasarkan pernyataan di atas maka dapat dikatakan bahwa perspekstif kekuatan merupakan amanah, sekaligus dasar filosofis dari profesi pekerjaan sosial. Salah satunya adalah pada prinsip hak untuk menentukan atau memutuskan dirinya sendiri. Klien diberi peluang dan kesempatan untuk memikirkan dan menentukan jalur hidupnya sendiri berdasarkan potensi dan sumber yang dimilikinya. Kebebasan untuk bertindak menentukan arah hidup berdasarkan potensinya tersebut juga dapat dipandang sebagai upaya pemberdayaan pada diri klien. Hal ini dapat dipandang penghargaan dan menghormati atas segala sumber dan potensi yang dimiliki oleh seseorang., termasuk juga keluarga dalam kategori miskin

Pendekatan berbasiskan kekuatan saat ini, secara pustaka telah menggeser pendekatan intervesi yang berlandaskan pada 'kesalahan' atau 'masalah'. Pendekatan kekuatan akan lebih fungsional, karena berlandaskan pada kekuatan-kekuatan dan sumber-sumber daya baik dari diri maupun lingkungan sekitar. Persoalannya adalah bagaimana diri atau keluarga tersebut dapat mengetahui dan memahami berbagai sumber dan kemungkinan-kemungkinan yang ada di dalam diri dan lingkungan sosialnya. (Sousa, Ribeiro \& Rodrigues, 2006: 190-191)

Selanjutnya Hammond (2010: 5) telah mengidentifikasi, bahwa para peneliti dan praktisi telah mengembangkan prinsip-prinsip utama atau inti (Core Principles of Strength-Based Practice) dalam praktik berbasis kekuatan. Pengembangan prinsip-prinsip utama tersebut dtujukan untuk memberi arah dan memandu dalam penerapan praktik berbasis kekuatan. Terdapat 9 (sembilan prinsip utama dalam praktik dan penelitian berbasis kekuatan, yaitu:

1) An absolute belief that every person has potential and it is their unique strengths and capabilities that will determine their evolving story as well as define who they are-not their limitations (not, I will believe when I see-rather, I believe and I will see).

2) What we focus on becomes one's reality-focus on strength, not labels-seeing challenges as capacity fostering (not something to avoid) creates hope and optimism.

3) The language we use creates our reality-both for the care providers and the children, youth and their families.

4) Belief that change is inevitable-all individuals have the urge to succeed, to explore the world around them and to make themselves useful to others and their communities.

5) Positive change occurs in the context of authentic relationships-people need to know someone cares and will be there unconditionally for them. It is a transactional and facilitating process of supporting change and capacity building-not fixing.

6) Person's perspective of reality is primary (their story)-therefore, need to value and start the change process with what is important to the person-not the expert.

7) People have more confidence and comfort to journey to the future (the unknown) when they are invited to start with what they already know.

8) Capacity building is a process and a goal-a life longjourney that is dynamic as opposed to static.

9) It is important to value differences and the essential need to collaborate-effective change is a collaborative, inclusive and participatory process-"it takes a village to raise a child". (Hammond, 2010:5)

Menurut Saleebey (1997: 12-15), terdapat lima prinsip yang mengarahkan asumsi perspektif kekuatan tersebut, pertama, setiap individu, kelompok, keluarga dan masyarakat memiliki kekua- 
tan. Perspektif kekuatan melihat sumber-sumber tersebut. Saleebey mencatat bahwa di tahap akhir, klien ingin mengetahui bahwa anda benar-benar membantu mereka, bahwa bagaimana melihat diri anda berbeda, bahwa anda akan mendengarkan mereka, bahwa anda akan menghargai diri mereka tidak perduli latar belakang mereka, dan bahwa anda yakin bahwa mereka dapat membangun sesuatu yang bernilai dengan sumber-sumber yang ada dalam diri dan di sekitar mereka. Tetapi yang terpenting, klien ingin mengetahui bahwa anda yakin bahwa mereka dapat mengatasi kemalangan dan mulai menapaki ke arah perubahan dan pertumbuhan.

Kedua, trauma, siksaan, sakit, dan perjuangan dapat membuat luka, tetapi hal tersebut dapat dijadikan sumber tantangan dan kesempatan/peluang. Klien yang telah menjadi korban dipandang sebagai individu aktif dan berkembang, melalui trauma, mereka belajar keterampilan dan atribut pengembangan diri yang membantu mereka menghadapi persoalan yang sama di masa mendatang. Kehormatan akan ditemui ketika mampu mengatasi hambatan-hambatan. Kita akan cepat tumbuh berkembang apabila kita mampu melewati krisis dan mampu mengatasi situasi secara efektif di setiap periode kehidupan.

Ketiga, diasumsikan bahwa anda sama sekali tidak mengetahui batas atas dari kapasitas untuk terus tumbuh dan berubah, dan melakukan aspirasi individu, kelompok dan masyarakat secara serius. Prinsip ini berarti bahwa pekerja sosial harus memegang harapan yang tinggi terhadap klien dan mengikatnya dengan visi, impian, dan nilai-nilainya. Individu, keluarga, dan masyarakat memiliki kapasitas untuk memantulkan dan memulihkan persoalan. Ketika pekerja sosial menghubungkannya dengan harapan dan impian klien, klien secara tepat memiliki keyakinan yang lebih besar. Sehingga seterusnya mereka mampu menempatkan upaya-upaya yang dibutuhkan untuk memenuhi harapan dan impian mereka sendiri.

Keempat, kita lakukan pelayanan terbaik kepada klien dengan berkolaborasi bersamanya, yang menciptakan potensi lebih besar akan dirinya sendiri. Seorang pekerja sosial akan lebih efektif jika dilihat oleh klien sebagai kolaborator atau konsultan daripada sebagai seorang ahli atau seorang professional. Sikap mental kolaboratif oleh seorang pekerja sosial membuat dia lebih rentan dengan beragam akibat kelemahan dari hubungan expert-inferior, termasuk pemolaan, victim-blaming, dan pesolek pandangan klien.

Kelima, setiap lingkungan penuh dengan sumber-sumber. Dalam setiap lingkungan (tidak perduli seberapa kerasnya) terdapat individu-individu, kelompok-kelompok, asosiasi, dan institusi dengan sesuatu untuk pemberian, dan dengan sesuatu kebutuhan lainnya mungkin menyedihkan. Perspektif kekuatan berupaya meng-identifikasi sumber-sumber tersebut dan membuat mereka keberadaannya bermanfaat bagi individu, keluarga, dan kelompok-kelompok dalam masyarakat.

Prinsip-prinsip tersebut begitu esensial penerapannya, khususnya berkaitan dengan proses awal pertolongan pekerjaan sosial, yaitu asesmen. Hasil dari asesmen ini akan ditentukan bersama (antara pekerja sosial dan klien) mengenai rencana kegiatan (plan of treatment) yang sekiranya tepat sesuai dengan sumber-sumber dan potensi yang dimiliki klien dan yang ada di sekitar klien. Namun, sebelum berlanjut perlu pula untuk melihat suatu kerangka asesmen, yang telah ada dan berkembang baik yaitu asesmen dengan kerangka bio-psiko-sosio-spiritual'; yang mencoba untuk secara menyeluruh melihat beragam dimensi dalam asesmen. 


\section{Penutup}

Pendekatan praktik berbasis kekuatan berlandas pada suatu keyakinan bahwa setiap orang memiliki potensi dan kekuatan-kekuatan unik serta terus berkembang. Fokus pada kekuatan berarti melihat tantangan sebagai kapasitas untuk terus membina dengan menciptaaan harapan dan optimisme. Dalam realitas keseharian, hal tersebut dapat muncul dalam berbahasa dengan membiasakan bahasa dan cara-cara yang memunculkan potensi mereka. Sikap menghargai dan mamfasilitasi merupakan tindakan-tindakan riil yang harus terus diupayakan. Konseskuensinya, lingkungan sosial sekitar harus mendukung suasana penguatan perspektif berbasis kekuatan.

Pekerjaan Sosial dapat dikatakan sebagai profesi yang kelahirannya sangat terkait dengan permasalahan kemiskinan, khususnya upaya membantu orang-orang yang menyandang masalah kemiskinan ini. Kemiskinan dapat dikatakan sebagai "major problem" bagi profesi ini. Pada awalnya Pekerjaan Sosial menggunakan perspektif berbasis masalah dalam menjalankan intervensinya membantu memecahkan masalah kemiskinan. Perspektif ini mendominasi intervensi yang dilakukan oleh para Pekerja Sosial hingga tahun 1980an. Sejak itu terjadi pergeseran perspektif dalam intervensi Pekerjaan Sosial yang ditandai dengan muncul perspektif berbasis kekuatan. Intervensi Pekerjaan Sosial mulai difokuskan pada upaya mendayagunakan sumber-sumber daya atau kekuatan yang pada penyandang masalah, termasuk orang miskin, baik internal maupun eksternal. 


\section{Bibliografi}

Akhmadi, 2006, Studi Keluar dari Kemiskinan Kasus di Komunitas RW 4, Dusun Kiuteta, Desa Noelbaki, Kecamatan Kupang Tengah, Kabupaten Kupang, Nusa Tenggara Timur, Lembaga Penelitian SMERU, Jakarta.

BPS, 2010, Profil Kemiskinan di Indonesia Maret 2010, Berita Resmi Statistik, BPS, No.45/07/Th. XIII, 1 Juli 2010, Jakarta.

Causes \& Effects of Poverty On Society, Children \& Violence poverties.org Research for social \& economic development-See more at: http://www.poverties.org/effects-of-poverty.html\#sthash.lFOQKxdi.dpuf Published March 2011 - Updated May 2013:8)

Francis, Tazoacha, 2001, The Causes and Impact of Poverty on Sustainable Development in Africa, A Paper Presented at The Conference "Poverty and Sustainable Development " Held In Bordeaux, France from November 22-23, 2001

Graeme Stuart, 2012, What is Strengths Perspective, Sustaining Cummunity

Laura Ellis and Elaine Weekse, 2011, Why Use a Strengths-Dede Approach Instead of a Deficit-Based Approach?, www.mtroyal.ca/cs/groups/public/.../pdf _why_ strengths_not_deficit.pdf

Maia Green, Representing poverty and attacking representations: some anthropological perspectives on poverty in development

Maryann Roebuck,2007, The Strength-Based Approach : Philosophy and Principles for Practice,

Natalie Scerra, 2011, Strength-Based Practice, The Evidence, a Discussion Paper, Research-Paper July 2011, Uniting Care Children, Young People, and Families, New South Wales)

Office of the United Nations High Commissioner for Human Rights Principles and Guidelines for Human Rights Approach to Poverty Reduction Strategies [online] Available at , http://www.ohchr.org/Documents/Publications/ PovertyStrategiesen. pdf $>$ [Accessed 10 January 2012] (Poverty Social Work Policy Institute http:// www.socialworkpolicy.org research/poverty.html 2feb2013)

Raharjo, S.T. 2016. Asesmen dan Wawancara dalam Praktik Pekerjaan Sosial dan Kesejahteraan Sosial. Unpad Press: Bandung. . 2015. Dasar Pengetahuan Pekerjaan Sosial. Unpad Press: Banung 2015. Keterampilan Pekerjaan Sosial: Dasar-dasar. Unpad Press: Bandung.

Schiller, Bradle R. 1998, The Economics of Poverty sn Discrimination, $7^{\text {th }}$ edition,Prentice Hall. New Jersey.

Tammie O’Nei, 2006, Human Rights and Poverty Reduction: Realities, Controversies and Strategies, An ODI Meeting Series (editorial), Overseas Development Institute 2006.

The World Bank , 2001, World Development Report 2000/2001, Attacking, (C) 2001 The International Bank for Reconstruction and Development/The World Bank, $1818 \mathrm{H}$ Street, N.W., Washington, D.C. 20433, U.S.A.

-----, 2009, Profil Kemiskinan di Indonesia Maret 2009, Berita Resmi Statistik BPS, No. 43/07/Th. XII, 1 Juli 2009 , Jakarta.

United Nations, 1995, World Summit for Social Development, Copenhagen, Denmark, www.un.org/documents/ga/conf166/aconf166-9.htm, diunduh 25agustus2015 
-, 2013, The Millennium Development Goals Report. New York, https://sites.google.com/site/solutionfocusedapproach/5-study-materials/2-strengths--based-approach-definition-history-philisophy-principles-and-practice

Wibhawa, B., Raharjo, S.T., Santoso., M.B. 2015. Pengantar Pekerjaan Sosial. Unpad Press: Bandung 